Available online at GSC Online Press Directory

GSC Biological and Pharmaceutical Sciences

e-ISSN: 2581-3250, CODEN (USA): GBPSC2

(RESEARCH ARTICLE)

\title{
Assessment of copper levels along the Namibian marine coastline
}

\author{
Omoregie Edosa 1, ${ }^{*}$, Vellemu Emmanuel Captain ${ }^{2}$, Nashima Festus ${ }^{3}$, Mudumbi Samona Brian ${ }^{4}$, Liswaniso \\ Gadaffi ${ }^{3}$ and Shimooshili Kaspar ${ }^{3}$ \\ 1 Department of Natural and Applied Sciences, Namibia University of Science and Technology, Private Bag 13388, \\ Windhoek, Namibia. \\ 2 Department of Water Resources Management, Malawi University of Science and Technology, Malawi. \\ 3 Department of Fisheries \& Aquatic Sciences, Sam Nujoma Campus, University of Namibia, P.O. Box 462, Henties Bay, \\ Namibia. \\ ${ }^{4}$ National Commission for Research, Science and Technology, Private Bag, 13253, Windhoek, Namibia.
}

Publication history: Received on 05 June 2019; revised on 15 June 2019; accepted on 21 June 2019

Article DOI: https://doi.org/10.30574/gscbps.2019.7.3.0101

\begin{abstract}
Elevated trace metal in the aquatic environment is a global challenge. In this investigation, copper (Cu) levels were assessed using inductively coupled plasma optical emission spectrometry (ICP-OES) during winter and summer months of 2012. The aim of this study was to determine the pollution status of Central Namibian coastline using copper levels in black mussel, sediments and water as indicators. Results indicated that $\mathrm{Cu}$ levels were significantly higher at Walvis Bay Harbour in mussels, sediments and water column $(\mathrm{P}<0.05)$. Levels between summer and winter were not significant $(\mathrm{P}>0.05)$. Black mussels at Walvis Bay Harbour could be regarded safe for consumption as the recorded levels were within the permissible limit set by the European Commission (EC. No.466/2001). However, further monitoring of the coastline is ecologically imperative to avoid human risks and irreversible ecological impacts.
\end{abstract}

Keywords: Copper; Choromytilus meridionalis; Coastal pollution; Harbour; Marine; Namibia

\section{Introduction}

Copper is an element believed to be present everywhere in nature. Like other elements, it may find its way to coastal waters due to both natural and anthropogenic processes. It is a trace metal which can accumulate in sediments due to plankton sedimentation, industrial and effluent discharges into the coastal waters [1]. As with most contaminants, copper may stay in the water column, settle at the bottom in sediments or be picked up by aquatic organisms such as Choromytilus meridionalis (black mussels) through filter feeding mechanism [2]. Copper is a metal which is commonly used as an antifouling paint in ship bottoms and molluscide in water [3]. Although it is an essential micronutrient needed by living organisms [4], copper has known toxic effects to aquatic organisms when present in high concentrations [5].

Several organisms such as mussels, oysters and limpets have been used as bio-monitors in many parts of the world because they are able to accumulate high levels of trace metals without any harmful effects [6, 7]. On the contrary, some organisms are known to be pollution sensitive and may not withstand minute concentrations [8].

The Namibian coastal ecosystems are at threat from various increasing industrial and human activities such as mining, human settlements and recreational activities which have, for many years, discharged effluents into these ecosystems [9]. These ecosystems also receive freshwater inputs from major non-perennial rivers such as the Swakopmund,

\footnotetext{
${ }^{*}$ Corresponding author

E-mail address: eomoregie@nust.na
} 
associated with a strong history of copper mining activity in its catchment areas [10]. In addition, Walvis Bay Harbour which is the largest in Namibia plays a substantial role for the country's economy.

This paper presents preliminary findings of copper levels assessed along the Central Namibian marine coastline specifically at the four coastal towns namely Cape Cross, Swakopmund, Henties Bay and Walvis Bay, the Harbour. The study also compares seasonal (winter and summer of the Southern Hemisphere) variation of copper levels found in $C$. meridionalis with those detected in sediments and in the water column.

The justification for this present study is based on the increased number of mariculture activities taking place within the vicinity of the Walvis Bay harbour and potential health hazards arising from possible metal contamination of farmed mussels destined for the local and international markets. This investigation has focused primarily on copper due to the increased number of vessels passing through the Walvis Bay Lagoon and then docking at the harbour and the numerous shellfish farms located within the vicinity. Copper being a major component added to ship paints as coating and antifouling agent have been documented to leach directly into the ocean [11], hence, there is a need for initial preliminary studies and to generate baseline data for monitoring and management purposes.

\section{Material and methods}

All samples were randomly collected from each of the following different locations (spread over $0.2 \mathrm{~km}$ within each

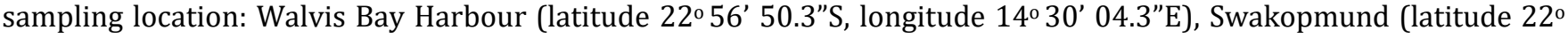

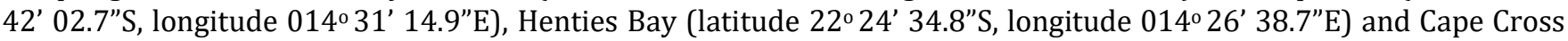

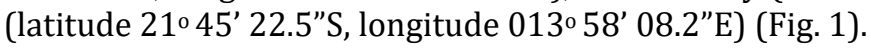

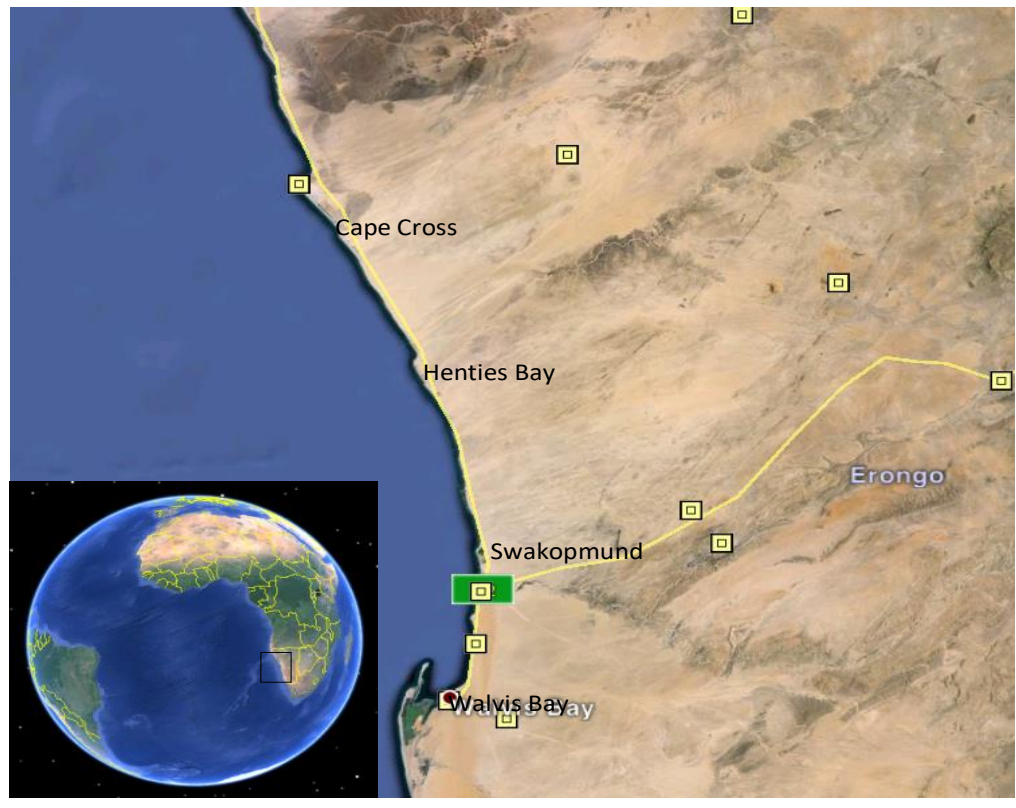

Figure 1 Namibian Coastline showing location of sampling stations (Source: Google Maps)

Walvis Bay is the largest commercial port in Namibia and is a haven for sea vessels, fishing factories and everincreasing number of human settlements. In the Southern part of Walvis Bay Harbour is a lagoon designated as a wetland of international importance under the RAMSAR Convention in 1995 [12]. Swakopmund site is well-known tourist attraction point coupled with several recreational activities due to the beautiful beaches and sand dunes; and so are the coastal towns of Henties Bay and Cape Cross. There are also various human settlements and tourism/accommodation industry businesses that are prevailing in all these coastal towns.

There were three factors in this study namely; stations (Walvis Bay, Swakopmund, Henties Bay and Cape Cross), season (winter and summer) and substrates (mussels, sediment and water). Winter season was demarcated as from April to July and summer season ranged from the end September to December in the same year.

A total of whole 96 live mussel $C$. meridionalis samples (between $3.5 \mathrm{~cm}$ and $9.6 \mathrm{~cm}$ standard length) were randomly selected between April and December 2012, except in August to separate the two seasons. From each of the stations, 
12 black mussel samples of similar sizes were randomly collected during low tide and treated as replicates in each season. Samples were collected during a low tide at different days, placed in clear labelled plastic bags containing seawater before being transported to the laboratory for digestion process. This procedure was also applied for collection of water and sediment samples. However, water samples were spiked by applying $3 \mathrm{ml}$ of nitric acid per litre of seawater to stabilise the metal content.

In situ observations of surface seawater temperature $\left({ }^{\circ} \mathrm{C}\right)$, dissolved oxygen (DO) and pH were measured during each sampling period. The temperature and $\mathrm{pH}$ values were measured using the Voltcraft PH-100 ATC pH meter while Dissolved Oxygen was determined by YSI 550-12 model DO meter.

Debris and stones were removed from sediment samples prior to air drying. All mussel and sediment samples were weighed using an analytical balance before drying in an oven at $70^{\circ} \mathrm{C}$ and $110^{\circ} \mathrm{C}$ for 48 hours respectively using a laboratory incubator (2000 Series model). Thereafter, the dried and weighed black mussel samples were pulverised using a pestle and mortar. Water samples were analysed on 'as is' basis because turbidity was less than 1 (NTU < 1). All samples were digested using the United States Environmental Protection Agency (EPA) 3050B protocol. Copper levels in the samples were determined by inductively coupled plasma optical emission spectrometry (ICP-OES), Perkin Elmer Optima 7, 000 DV model. The results were expressed as mean copper levels in parts per million (ppm).

Data were first tested for normality using the Kolmogorov-Smirnov test and analysed using a 4x2x3 factorial model of a completely randomised Analysis of variance (ANOVA) design on a computer software package GENSTAT Discovery Edition 4 (VSN International, Hertfordshire HP1 1ES, UK). Comparisons of means for copper levels between and within mussels, sediments and water column were performed using the least significant difference (LSD) technique at 0.05 level of significance.

\section{Results}

Various environmental water parameters measured during the study (Table 1) showed that the pH was significantly different $(\mathrm{p}<0.05)$ between winter and summer with mean values of 8.37 and 6.74 respectively. However, temperature and dissolved oxygen values obtained for both seasons were not significantly different $(p>0.05)$.

There was a high significant difference $(\mathrm{p}<0.05)$ of mean $\mathrm{Cu}$ levels detected at the four different stations of the Central Namibian marine coastline. Walvis Bay station had the most copper levels which were statistically significant $(\mathrm{p}<0.05)$ compared to the other three stations. The LSD test results revealed that there were no significant differences $(\mathrm{p}>0.05)$ in $\mathrm{Cu}$ levels found between Swakopmund and Henties; and, between Swakopmund and Cape Cross stations.

Results showed a high significant difference $(\mathrm{p}<0.05)$ of $\mathrm{Cu}$ levels detected in substrates (water, mussels and sediments) along the Central Namibian marine coastline. Sediments had accumulated more Cu followed by mussels with water accumulating the least $\mathrm{Cu}$ levels exclusive to Walvis Bay station during summer (Fig. 2) and winter (Fig. 3). Further analysis indicated that there was no significant interaction ( $p>0.05)$ between winter and summer Cu levels. Additionally, no significant interaction was found between stations and seasons despite a slight increase of Cu levels at Walvis Bay Harbour during winter season.

A high significant interaction $(\mathrm{p}<0.05)$ of $\mathrm{Cu}$ levels was detected between stations and substrates (Fig. 4). Sediments accumulated more $\mathrm{Cu}$ than water and $C$. meridionalis with mean value of $36.16 \pm 5.34 \mathrm{ppm}$ at Walvis Bay Harbour. No copper level was recorded in water samples at Swakopmund, Henties Bay and Cape Cross stations while 0.05 ppm of Cu was detected at Walvis Bay station during summer (Fig. 4).

Using the LSD technique to separate the means for $\mathrm{Cu}$ between the stations, significant differences $(\mathrm{p}<0.05)$ of means were found in all stations except for Swakopmund and Henties Bay; and; Cape Cross and Swakopmund. In addition, all means for $\mathrm{Cu}$ between each of the substrates tested were significantly different $(\mathrm{p}<0.05)$. 
Table 1 Mean values $( \pm \mathrm{SE}$ ) of surface seawater temperature, dissolved oxygen and $\mathrm{pH}$ values along the Central Namibian marine coastline.

\begin{tabular}{lll}
\hline Parameter & Winter & Summer \\
\hline Temperature $\left({ }^{\circ} \mathrm{C}\right)$ & $15.83 \pm 0.09$ & $16.38 \pm 0.27$ \\
Dissolved Oxygen $(\mathrm{ppm})$ & $6.37 \pm 0.44$ & $6.83 \pm 0.72$ \\
$\mathrm{pH}$ & $8.37 \pm 0.053$ & $6.74 \pm 0.230$ \\
\hline
\end{tabular}

$\mathrm{SE}=$ Standard Error of mean

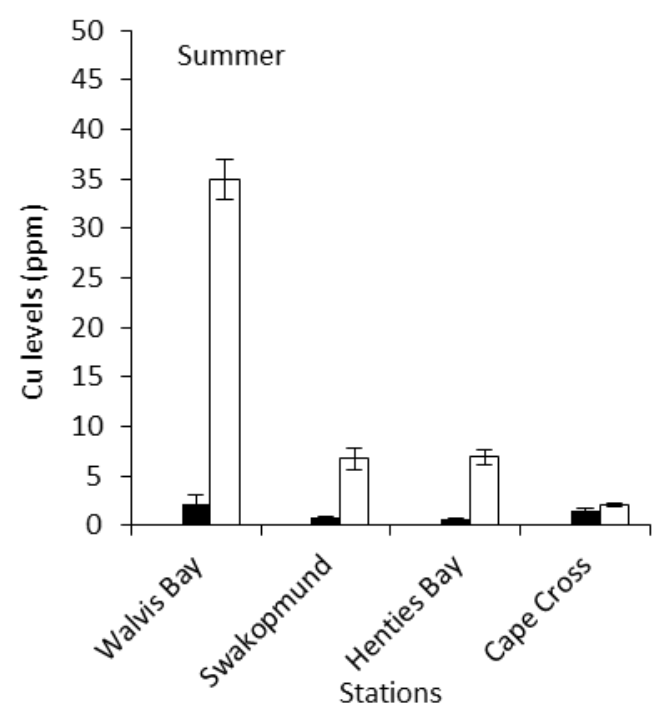

Figure 2 Copper levels accumulated by substrates at different stations along the Central Namibian marine coastline during summer

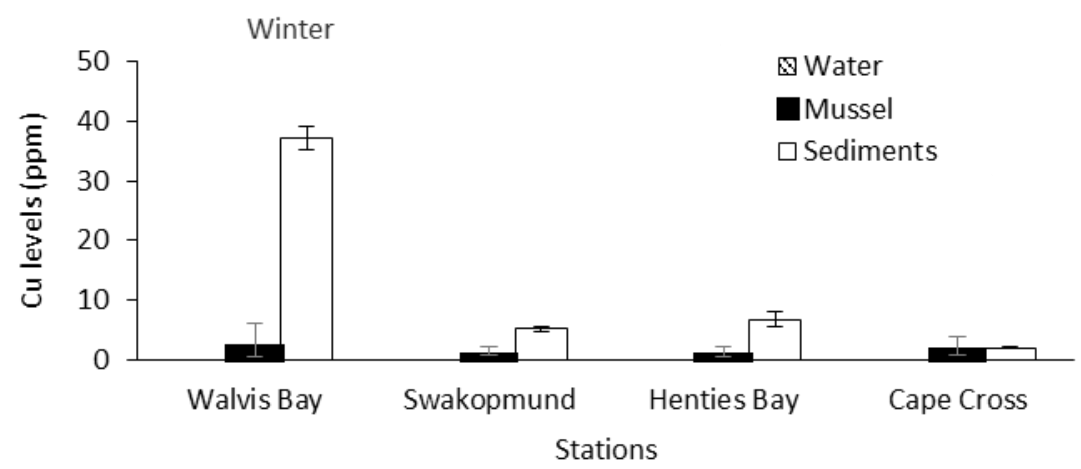

Figure 3 Copper levels accumulated by substrates at different stations along the Central Namibian marine coastline during winter 

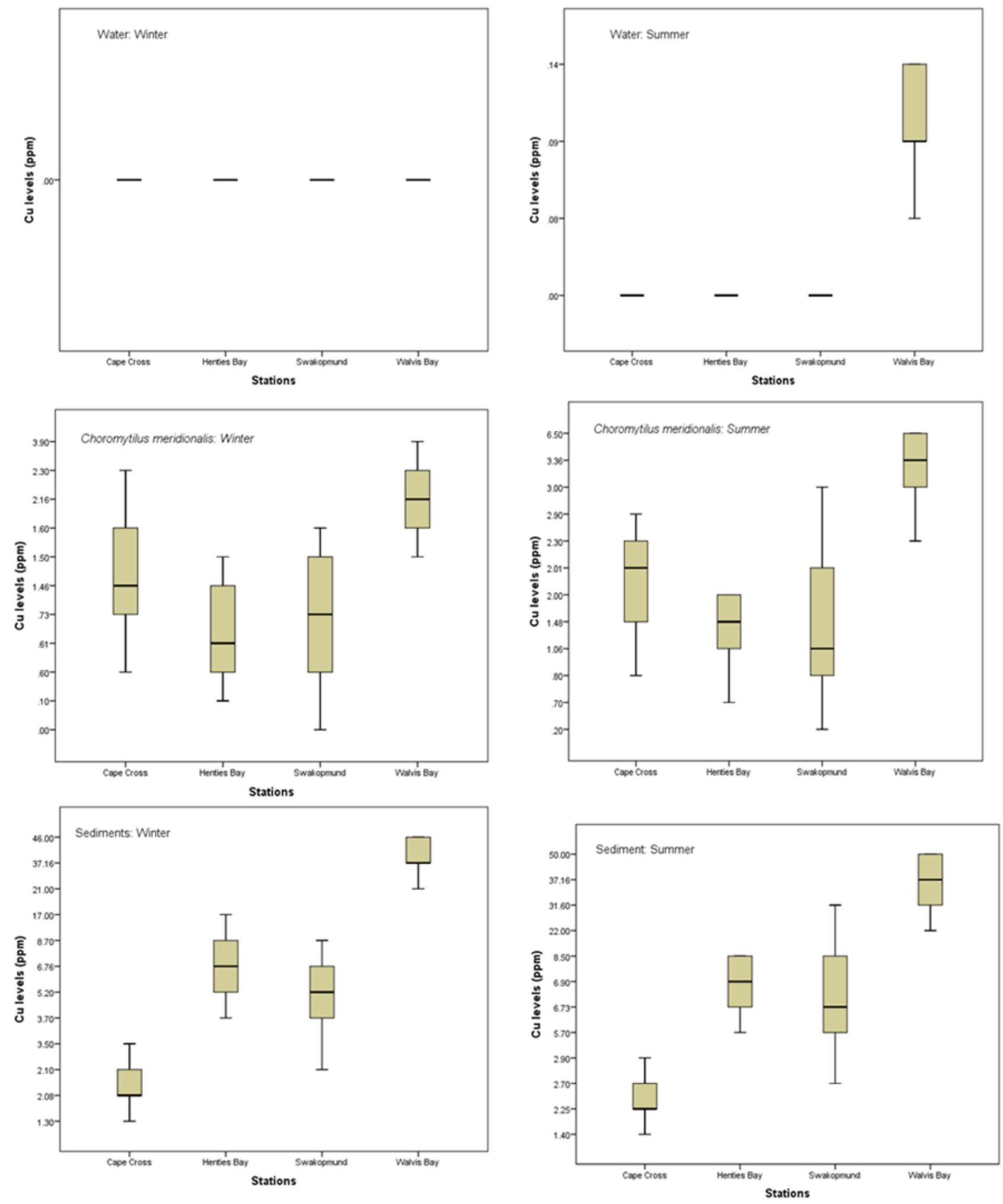

Figure 4 Copper levels accumulated in water samples, mussels and sediments at different stations during winter and summer along the Namibian marine coastline 


\section{Discussion}

Natural waters become contaminated when the contaminant material disturbs the natural balance of living organisms near or in the water or when it makes the water unsafe for human consumption or recreation [13]. Anthropogenic activities are the most driving factors of water pollution worldwide [14] and usually, these occur in the catchment areas.

The $\mathrm{pH}$ value of water is a vital indication of its quality and usually depends on the carbon-dioxide carbonatebicarbonate equilibrium. Acid-base reactions, temperature and dissolved oxygen are quite significant affecting primary productivity [15]. Although recorded $\mathrm{pH}$ levels in this study were significant, they were in a range of 7.94 8.67 during winter and $4.67-8.59$ during summer season. The mean value recorded in winter where observed to be within normal mean of 8.4 [16]. However, the low pH recorded during summer could have be due to effluent discharges from the fishing industry around Walvis Bay and wastes from the seal colony at the Cape Cross sampling stations.

Copper is an important element for mussels which have a biological mechanism to regulate it. This current study revealed a significant increase of $\mathrm{Cu}$ levels at Walvis Bay Harbour, a trend which was similar to the trend in the Spanish coast of Galicia and Catabria [17]. The main potential sources of pollution evidently seen at present around the Harbour are the discharges from fishing factories and ship repairs, several recreational activities including an ever-increasing number of human settlements in the industrial town of Walvis Bay. This also corresponds with the findings of Taylor and Kesterton [10] who reported that there are high levels of Cu produced in the catchment areas of this study dating back as far as 1916.

The higher levels of $\mathrm{Cu}$ recorded in sediment samples could be due to the ability of sediments to act as an adsorptive sink for trace metals in a water body [18]. It is also widely recognised that sediments usually contain higher levels of trace metals due to geological evolution of rocks and seabed disturbance by mining activities or fishing dredging e.g. bottom trawlers. It is observed from this study that the mean copper levels detected in water samples at Walvis Bay Harbour during summer was $0.05 \mathrm{ppm}$, exceeded the permissible safe limit of $0.01 \mathrm{ppm}$ [19], however, levels from the other sampling stations were within limits.

Furthermore, findings of this study indicated a $100 \%$ positive relationship in terms of accumulation in Choromytilus meridionalis, sediment and water samples. This observation is similar to the findings of Boateng et al. [20] who studied Galatia paradoxa in the Volta Estuary and had observed a peak accumulation of different but similar metal manganese within the same study months in the same Southern Hemisphere climatic conditions. Additionally, a possible explanation of $\mathrm{Cu}$ accumulation between winter and summer seasons could partly be due to the reproductive activity of mussels [21] as gonadal development might be attributed to the accumulation of proteins and carbohydrates during spawning; and for gonad tissue production and energy consumption [20]. It has been reported that these organisms develop features that have affinity to trace metals during the reproduction cycle [20]. However, reproduction was not the focus for this study.

In addition, $\mathrm{Cu}$ levels in mussels could be attributed to age and size factors [22] although this study did not evidence this. $\mathrm{Cu}$ has also been reported to be a significant part of several enzymes and is necessary for the synthesis of haemoglobin in the body [23]. However, a high intake of this trace metal has been documented to cause adverse health problems [24]. Thus, the results of this study could infer that Walvis Bay Harbour is relatively more polluted in terms of $\mathrm{Cu}$ levels than those reported in Palk Bay and Gulf coastline of Mannar of the Indian Ocean [25]. This should cause grave concerns because there are aquaculture farms around the Walvis Bay Harbour.

This study has revealed that there is a significant level of copper within the sediments of the Walvis Bay Harbour. This observed elevated level should pose concern as most of the Namibian shellfish farms are located at the vicinity of the harbour. This study has demonstrated the urgent need to have a pollution monitoring and management program in place for the protection of farmed shellfish products. There is also the need to carry on with monitoring studies and to generate baseline data for monitoring purposes. 


\section{Compliance with ethical standards}

\section{Acknowledgments}

This study was wholly funded by NAMSOV Community Trust. The authors acknowledge the technical and logistical assistance received from the Sam Nujoma Marine and Coastal Resources Centre (SANUMARC) staff, Fisheries and Aquatic Sciences Department staff, Windhoek Analytical Services and Kuiseb Fishing Enterprise (KFE).

\section{Disclosure of conflict of interest}

The authors declare no conflict of interest.

\section{References}

[1] Garcia CAB, Garcia HL, Viana RD and Vian CLB. (2013). Efeito de biossolodos em argissolo acinzentado com fragia dos tabuleiros costeiros do estado de sergipe. Proceeding of Safety and Health Environment World Congress 12, 300-304.

[2] Vellemu EC and Omoregie E. (2014). Lead Pollution: A growing concern along the Namibian coastal waters. Internat Sc Technol J Namibia, 3, 21-34.

[3] Schiff K, Diehl D and Valkirs A. (2004). Copper emissions from antifouling paint on recreational vessels. Marine Pollution Bulletin 48, 371-377.

[4] Scheineberg IH. (1991). Copper. In: E. Merian (ed) Metals and their compounds in the environment. Wiley VCH Wienheim, Germany, 803-851.

[5] Long ER, Macdonald DD, Smith SL and Calder FD. (1995). Incidence of adverse biological effects within ranges of chemical concentrations in marine and estuarine sediments. Environmental Management 19, 81-97.

[6] Viarengo A and Canesi L. (1991). Mussels as biological indicators of pollution. Aquaculture 94, 225-243.

[7] Omoregie E and Ufodike EBC. (2000). Effects of water-soluble fractions of crude oil on growth of the Nile tilapia, Oreochromis niloticus (L). Bulletin of Environmental Contamination and Toxicology, 64, 601-604.

[8] Akueshi EU, Omoregie E, Ocheakiti N and Okunsebor S (2003). Levels of some heavy metals in fish from mining lakes on the Jos Plateau, Nigeria. African Journal of Natural Sciences 6, 82-86.

[9] World Bank. (2009). Namibia: Country Brief. The International Bank for Reconstruction and Development / World Bank Country Brief Publication Series. Washington D.C. 55.

[10] Taylor MP and Kesterton RGH. (2002). Heavy metal contamination of an arid river environment: Gruben River, Namibia. Geomorphology, 42, 311-327

[11] Lloyd R. (1992). Pollution and fresh water fish. West Byfleet: Fishing News (Books) Ltd, 195.

[12] Curtis B, Roberts KS, Griffin M, Bethune S, Hay CJ and Kloberg H. (1998). Species richness and conservation of Namibian freshwater macro-invertebrates, fish and amphibians. Biodiversity and Conservation, 7,447-466.

[13] Davies BR and Wishart MJ. (2000). River conservation in the countries of the Southern African Development Community (SADC). In: Boon PJ, Davies BR, Petts GE (eds) Global Perspectives on River Conservation. Science, Policy and Practice. Wiley, London, 179-204.

[14] Hickey GL, Kefford BJ, Dunlop JE and Craig PS. (2008). Making species salinity sensitivity distributions reflective of naturally occurring communities: Using Rapid Testing and Bayesian Statistics. Society of Environmental Toxicology and Chemistry 27, 2403-2411.

[15] Abida B, HariKrishna S and Irfanulla K. (2009). Analysis of Heavy metals in water, sediments and fish samples of Madivala Lakes of Bangalore, Karnakata: International Journal of ChemTech Research, 1, 245-249.

[16] WHO. (1987). Evaluation of certain food additives and contaminants. Thirty-third report of joint FAO/WHO expert committee on food additives, Geneva. World Health Organisation Technical Report Series, 776- 80.

[17] Besada V, Andrade JM, Schultze F and Gonzalez JJ. (2011). Monitoring of heavy metals in wild mussels (Mytilus galloprovincialis) from Spanish North-Atlantic coast. Continental Shelf Research, 31, 457-65. 
[18] Giarratano E and Amin OA. (2010). Heavy metals monitoring in the southernmost mussel farm of the word (Beagle Channel, Argentina). Ecotoxicology and Environmental Safety, 73, 1370-1384.

[19] European Community. (2001). Setting maximum levels for certain contaminants in food stuffs. Commission Regulation (ED) No. 466/2001, 13.

[20] Boateng AD, Obirikorang KA, Amisah S, Madkour HA and Otchere FA. (2011). Relationship between gonad maturation and heavy metal accumulation in the clam, Galatea paradoxa (Born 1778) from the Volta Estuary, Ghana. Bulletin of Environmental Contamination and Toxicology, 87, 626-632.

[21] Cardellicchio N, Buccolieri A, Leo AD, Giandomenico S and Spada A. (2008). Levels of metals in reared mussels from Taranto Gulf (Ionian Sea, Southern Italy). Food Chemistry 107, 890-896.

[22] Pip E. (1995). Cadmium, lead and copper in freshwater mussels from the Assiniboine River, Manitoba, Canada. Journal of Molluscan Studies 61, 295-302.

[23] Sivaperumal P, Sankar TV and Viswanathan PG. (2007). Heavy metal concentrations in fish, shellfish and fish products from internal markets of India vis-à-vis international standards. Food Chemistry, 102, 612-620.

[24] Gorell JM, Johnson CC, Rybicki BA, Peterson EL, Kortsha GX and Brown GG. (1997). Occupational exposures to metals as risk factors for Parkinson's disease. Neurology, 48, 650-658.

[25] Sulochanan B, Krishnakumar PK, Prema D, Kaladharan P, Valsala KK, Bhat GS and Muniyandi K. (2007). Trace metal contamination of the marine environment in Palk Bay and Gulf of Mannar. Journal of the Marine Biological Association of the United Kingdom 49, 12-18.

\section{How to cite this article}

Omoregie E, Vellemu EC, Nashima F, Mudumbi SB, Liswaniso G and Shimooshili K. (2019). Assessment of copper levels along the Namibian marine coastline. GSC Biological and Pharmaceutical Sciences, 7(3), 48-55. 